\title{
Trade and Child Labour in SAARC Countries
}

\author{
BILAL TARIQ ${ }^{1}$, ROSSAZANA AB-RAHIM ${ }^{2}$ \\ ${ }^{1}$ COMSATS University Islamabad, Pakistan. \\ Universiti Malaysia Sarawak, Malaysia. Email: arrossazana@unimas.my
}

\begin{abstract}
A review of past studies shows that the studies confine their analysis of trade and child labour in the setting of the trading of homogeneous goods. Hence, the presence study aims to assess the relationship of trade and child labour in South Asian Association for Regional Cooperation (SAARC) countries by incorporating the role of selection of variety or product heterogeneity in child labour demand. In the context of trade in homogeneous and heterogeneous goods, the trade-induced effects are the selection, scale, and technique effects. The panel data analysis is employed to investigate the nexus between trade and child labour over the study period of 1999 to 2019. The results imply that the opening of trade alone will not reduce child labour if it is not accompanied by supportive measures, namely the trade-related effect of child labour, the effect of scale and technique. Therefore, this study suggests that trade liberalization through trade-induced effect would hamper the child labour presence in the emerging markets.
\end{abstract}

Keywords: Child Labour, Trade Openness, Selection Effect, Scale Effect

JEL classification: F1, J4, J20

Recibido: 2 de Diciembre de 2020

Aceptado: 14 de Diciembre 2020 